\title{
ZASADY POSTĘPOWANIA W SPRAWACH Z ZAKRESU DZIALALNOŚCI GOSPODARCZEJ UNORMOWANE W USTAWIE PRAWO PRZEDSIĘBIORCÓW
}

\section{ZAŁOŻENIA, CEL I ZAKRES ARTYKUŁU}

Prawo przedsiębiorców ${ }^{1}$ jest czwartą z kolei ustawą normującą podejmowanie, wykonywanie i zakończenie działalności gospodarczej w porządku prawnym opartym na zasadzie wolności gospodarczej ${ }^{2}$. Trudno nie odnieść się do tego faktu. Jednym z pytań, jakie się nasuwa, jest to, czy częste zmiany regulacji mającej stworzyć ramy prawne funkcjonowania przedsiębiorczości w Polsce, w szczególności przez unormowanie zasad podejmowania, wykonywania i zakończenia działalności gospodarczej, nie naruszają zasady pewności prawa, która znajduje wyraz także w Pr.przeds. (zob. preambuła, art. 14, a także art. 33, art. 34 i art. 35 ust. 4). Temat artykułu nie wymaga całościowej oceny przepisów nowej ustawy, która pozwoliłaby na pełną odpowiedź na takie pytanie. Z pewnością jednak jednym z kryteriów/przesłanek umożliwiających wypowiedzenie się na podniesione pytanie jest to, czy Prawo przedsiębiorców normuje nowe zagadnienia lub normuje już objęte porządkiem prawnym kwestie szerzej lub inaczej niż obowiązująca poprzednio ustawa (ustawy).

Taka materia, która może być rozważana we wskazanym aspekcie, sa zasady kwalifikowane $\mathrm{w}$ doktrynie $\mathrm{w}$ ich najszerszym ujęciu jako zasady publicznego prawa gospodarczego ${ }^{3}$ lub zasady podstawowe (ogólne) publicznego (administracyjnego) prawa gospodarczego ${ }^{4}$. Bardziej szczegółowe

1 Ustawa z 6 marca 2018 r. - Prawo przedsiębiorców, Dz. U. 2018, poz. 646 (dalej jako: Pr.przeds.).

${ }^{2}$ Uwzględniam tu także ustawę z 23 grudnia 1988 r. o działalności gospodarczej, Dz. U. $\mathrm{Nr}$ 41, poz. 324 [dalej jako: u.d.g.] (uchylona na mocy ustawy Prawo działalności gospodarczej [P.d.g.]), choć bowiem wydana w poprzednim ustroju polityczno-gospodarczym, to jednak przyjmowała za podstawę prowadzenia działalności gospodarczej w sektorze prywatnym zasadę wolności gospodarczej.

3 Tak w podręczniku: K. Strzyczkowski, Prawo gospodarcze publiczne, LexisNexis, Warszawa 2011 , s. $79-115$.

${ }^{4}$ Tak w podręczniku: A. Borkowski et al. (red.), Administracyjne prawo gospodarcze, Kolonia Limited, Wrocław 2003, s. 11-67. Z ostatnich pozycji tak tė̇ M. Biliński et al., Zasady ogólne publicznego prawa gospodarczego, w: R. Hauser, Z. Niewiadomski, A. Wróbel (red.), System prawa administracyjnego, t. 8A: Publiczne prawo gospodarcze, C.H. Beck, Warszawa, s. 459-542. 
kwalifikacje wyodrębniaja „,swoiste zasady publicznego (administracyjnego) prawa gospodarczego" ${ }^{5}$. Nie rozważając w tym miejscu zagadnień pojęciowych, należy stwierdzić, iż Pr.przeds. normuje kwestie zasad związanych z podejmowaniem i wykonywaniem działalności gospodarczej zdecydowanie inaczej, niż czyniła to ustawa o swobodzie działalności gospodarczej (u.s.d.g.). Chodzi nie tylko o szerszy ich „katalog”, ale przede wszystkim o sposób regulacji: miejsce i sposób redakcji przepisów. Wstępnie można mówić o innej koncepcji uregulowania zasad, co jednak nie znaczy, że ich unormowanie można uznać za przemyślane i konsekwentnie zrealizowane. Te kwestie będą przedmiotem dalszych rozważań. Z pewnością jednak określone w Pr.przeds. zasady związane z działalnością gospodarcza, zwłaszcza dotyczace procedur $\mathrm{w}$ relacjach między administracją a przedsiębiorcami, stanowią w dużej mierze nową materię regulacji publicznego prawa gospodarczego.

W związku z tym w zbiorze artykułów dotyczacych zagadnień unormowanych w Pr.przeds. nie może zabraknać analizy tych przepisów, które m.in. zawierają wcześniej nieznane publicznemu prawu gospodarczemu treści normatywne. Jak wynika z tytułu artykułu, zainteresowanie autorki skupione zostanie na tych zasadach, które dotyczą postępowania w sprawach z zakresu działalności gospodarczej.

Takie określenie zakresu badań wymaga wskazania tych przepisów Pr.przeds., które zawierają wypowiedzi określane w teorii prawa jako zasady (o tym będzie mowa w następnym punkcie), z koncentracją na tych zasadach, które dotyczą dynamiki relacji między adresatami Pr.przeds., którymi są organy władzy publicznej (głównie organy administracji publicznej właściwe w sprawach gospodarki) i przedsiębiorcy (art. 1 Pr.przeds.), a więc dotycza postępowania, procedur i trybów. Prima facie wydaje się, że miejscem unormowania takich zasad powinien być rozdz. 3 Pr.przeds.: Załatwianie spraw z zakresu działalności gospodarczej. Dodać należy, że żadna z wcześniejszych ustaw nie zawierała przepisów zebranych w odrębny rozdział pod taką nazwą.

Termin „załatwianie spraw” jest terminem prawa i doktryny postępowania administracyjnego. Rozdział 7 ustawy z 14 czerwca 1960 r. - Kodeks postępowania administracyjnego ${ }^{6}$ pod takim tytułem zawiera rozwiązania służące zapewnieniu niezbędnej szybkości działania administracji publicznej, łącząc tę zasadę z postępowaniem jurysdykcyjnym ${ }^{7}$. Pojawia się zatem pytanie, czy ustawodawca w Prawie przedsiębiorców użył wskazanego zwrotu w tym samym znaczeniu, a może w przepisach tego rozdziału unormowane sa też inne zasady postępowania. A może kolejne zasady postępowania unormowane są w innych rozdziałach Pr.przeds.? Jeżeli tak, to czy stanowia one uporządkowany zbiór?

${ }^{5}$ A. Borkowski et al., op. cit., s. 61-65.

${ }^{6}$ T.jedn.: Dz. U. 2017, poz. 1257 ze zm. (dalej jako: k.p.a.).

${ }^{7} \mathrm{~W}$ nauce o postępowaniu administracyjnym przypisuje się tym rozwiązaniom walor ogólnej zasady postępowania, zob. B. Adamiak, w: A. Borkowski, B. Adamiak, Kodeks postepowania administracyjnego. Komentarz, C.H. Beck, Warszawa 2017, s. 280. 
Należy mieć na uwadze, że wcześniejsze ustawy dotyczące działalności gospodarczej, zwłaszcza u.s.d.g. (w mniejszym zakresie P.d.g.) normowały zasady dotyczące działalności gospodarczej, w tym dotyczace relacji procesowych z organami administracji publicznej, przede wszystkim w rozdz. 1: Przepisy ogólne, ale i w innych rozdziałach. To zobowiązuje do objęcia badaniami także innych przepisów Pr.przeds., w tym zwłaszcza zamieszczonych w rozdz. 1: Przepisy ogólne.

Uwzględniając powyższe, przyjmuję, że zadaniem artykułu jest ustalenie reguł/zasad dotyczacych postępowania $\mathrm{w}$ relacjach podmiot administracji przedsiębiorca w świetle przepisów Prawa przedsiębiorców i ich charakterystyka w zakresie, na jaki pozwalają ramy opracowania. Celem zaś jest próba odpowiedzi na pytanie, czy rozwiązania te stanowią spójny (uporządkowany) zbiór zasad postępowania w wyżej wymienionym zakresie, a w przypadku pozytywnej odpowiedzi - czy taki zbiór mógłby służyć za podstawę proceduralnego publicznego prawa gospodarczego (bazę normatywną wszelkich innych rozwiązań $\mathrm{w}$ zakresie postępowania $\mathrm{w}$ relacjach podmiot administracji - przedsiębiorca).

Jak już wspomniano, materia tu rozważana była również przedmiotem regulacji u.s.d.g., stąd narzucające się porównania i nawiązania do pogladów wyrażonych wcześniej na tle jej regulacji. Oczywiste też jest, że dla pewnych rozwiązań procesowych, unormowanych w Pr.przeds., płaszczyzną odniesienia będą instytucje postępowania administracyjnego, w tym zwłaszcza k.p.a., a konkretnie - zasady ogólne postępowania administracyjnego, uznawane za standardy „dobrej administracji”, z uwzględnieniem noweli z 7 kwietnia 2017 r. ${ }^{9} \mathrm{~W}$ związku z tym w niezbędnym zakresie wykorzystany zostanie dorobek teorii prawa administracyjnego i prawa postępowania administracyjnego. Zaznaczyć jednak należy, że prowadzone tu rozważania nie są nastawione na teoretycznoprawną analizę poszczególnych instytucji procesowych unormowanych w Pr.przeds. (tym bardziej w k.p.a.), która jest właściwa opracowaniom o charakterze komentarza. Niezależnie od powyższego zastrzeżenia, intencją autorki niniejszego artykułu jest, by służył on pogłębieniu rozważań nad zagadnieniami procesowego publicznego prawa gospodarczego, z ukierunkowaniem na znaczenie zasad unormowanych w Pr.przeds. ${ }^{10}$

${ }^{8}$ Pod tym pojęciem kryją się konkretne wymagania stawiane administracji, odpowiadające podstawowym wartościom konstytucyjnym, oraz tym wartościom, które stanowią podstawę określonych regulacji materialnoprawnych. Zob. monografię M. Princa, Standardy dobrej administracji w prawie administracyjnym, Poznań 2016, zwł. s. 67-79 i wskazaną tam literaturę.

${ }^{9}$ Dz. U. 2017, poz. 935 (dalej też jako: nowela k.p.a. z 2017).

${ }^{10}$ Obszerniejsze omówienie tego aspektu wymagać będzie dalszych badań, uwzględniających różnorodność procedur stosowanych przez administrację publiczną w sferze gospodarki. Zob. B. Popowska, Nowe procedury publicznego prawa gospodarczego. Problem gwarancji procesowych dla podmiotów działalności gospodarczej, Acta Universitatis Wratislaviensis No 3833, Przegląd Prawa Administracyjnego 114, Wrocław 2018, s. 591-605. 


\section{ZASADY PRAWA, ZASADY OGÓLNE, ZASADY POSTĘPOWANIA}

Pojęcie zasad prawa należy do kanonu pojęć teorii prawa ${ }^{11}$; do znaczenia nadawanemu temu pojęciu $\mathrm{w}$ tej nauce nawiązują dyscypliny szczegółowe ${ }^{12}$. $\mathrm{Z}$ reguły $\mathrm{w}$ doktrynie poszczególnych gałęzi prawa używa się tego pojęcia w znaczeniu dyrektywalnym, poszukując zasad w źródłach prawa szczególnej rangi, jak Konstytucja RP, kodeksy. Wiąże się to z właściwością źródeł prawa o wysokiej pozycji hierarchicznej w systemie, że formułują one normy-zasady, nadrzędne w stosunku do innych norm tego systemu, wyznaczające ich adresatom szczególnie doniosłe zachowania merytoryczne czy wartości, które powinny być realizowane za pomoca norm danego systemu.

Jednym z argumentów za poszukiwaniem zasad w znaczeniu dyrektywalnym w przepisach Pr.przeds. jest ranga tej ustawy (podobnie jak i poprzednich ustaw, zwłaszcza: P.d.g. i u.s.d.g.). O jej wysokiej pozycji świadczy m.in. przedmiot jej regulacji, którym sa zagadnienia związane wprost z konstytucyjną zasadą wolnościa działalności gospodarczej (stanowiąca jedna z podstaw ustroju RP - art. 20), jak i znajdująca się w tytule ustawy nazwa „Prawo....” ${ }^{13}$, oraz zamieszczenie w niej preambuły. Należy zgodzić się z pierwszymi wypowiedziami piśmiennictwa oceniającymi przepisy Pr.przeds., że ustawa ta (podobnie jak i poprzednie) ma kluczowe znaczenie w ramach systemu publicznego prawa gospodarczego; jest ustawą podstawowa ${ }^{14}$. Z taką pozycją tej ustawy wiąże się także szczególne znaczenie zasad w niej unormowanych. Wynika ono także $\mathrm{z}$ tego faktu, że w ramach gałęzi publicznego prawa gospodarczego nie sa odrębnie unormowane (skodyfikowane) reguły postępowania między podmiotem administracji i przedsiębiorca, na wzór k.p.a. ${ }^{15} \mathrm{~W}$ tym stanie rzeczy zasady odnoszące się do stosunków między administracją a przedsiębiorcami w zakresie podejmowania, wykonywania i zakończenia działalności gospodarczej,

${ }^{11}$ Zob. zwłaszcza A. Redelbach, S. Wronkowska, Z. Ziembiński, Zarys teorii państwa i prawa, WN PWN, Warszawa 1994, s. 224-227. Teoretycy prawa rozróżniają dwa znaczenia tego pojęcia: opisowe i dyrektywalne.

${ }^{12} \mathrm{O}$ wieloznaczności pojęcia „zasady prawa” oraz możliwościach ich kategoryzowania w zależności od przyjętych kryteriów i potrzeb zob. J. Zimmermann, Prawo administracyjne, Wolters Kluwer, Warszawa 2016, s. 161-162; S. Tkacz, Podstawowe sposoby rozumienia zasad prawa, w: J.P. Tarno, W. Piątek (red.), System prawa procesowego administracyjnego, t. 2, cz. 2: Zasady ogólne postępowania administracyjnego, C.H. Beck, Warszawa 2018, s. 21-26.

${ }_{13}$ Zob. $§ 9$ w zw. z $§ 2$ rozporządzenia Prezesa Rady Ministrów z 20 czerwca 2002 r. w sprawie „Zasad techniki prawodawczej”, t.jedn.: Dz. U. 2016, poz. 283.

${ }^{14}$ Zob. zwłaszcza M. Zdyb, Podstawowe zasady (standardy) tadu gospodarczego $w$ świetle ustawy z 6.3.2018 r. - Prawo przedsiębiorców, „Monitor Prawniczy” 2018, nr 13, Dodatek Specjalny, s. 5 i 12.

${ }^{15}$ Wynika to głównie $\mathrm{z}$ tego, że między obu rodzajami podmiotów zachodzą relacje różnego typu, w zależności od sfery działania administracji publicznej, jej zadań/funkcji. Zob. B. Popowska, Publiczne prawo gospodarcze w ptaszczyźnie proceduralnej, w: L. Kieres (red.), Nowe problemy badawcze $w$ teorii publicznego prawa gospodarczego ( $z$ uwzględnieniem samorzadu terytorialnego), Kolonia Limited, Wrocław 2017, s. 209-242; eadem, Klasyfikacja funkcji administracji $w$ nauce publicznego prawa gospodarczego, w: B. Popowska (red.), Funkcje wspótczesnej administracji gospodarczej, Poznań 2006, s. 61-86. 
niezwiązane z konkretną sferą gospodarki, uznaje się za zasady uniwersalne $\mathrm{W}$ systemie publicznego prawa gospodarczego ${ }^{16}$.

Jak już podkreślano, przedmiotem ustaleń w ramach tego artykułu są,zasady dotyczące postępowania”. To znaczy jakie? Najłatwiej byłoby nawiązać do wyróżnianych w doktrynie (odpowiednio do rodzajów norm) zasad prawa: ustrojowego, materialnego i postępowania (procesowe) ${ }^{17}$. Jak jednak podkreśla się w doktrynie prawa administracyjnego i orzecznictwie Naczelnego Sądu Administracyjnego, nawet „zasady ogólne w Kodeksie postępowania administracyjnego swoją treścią znacznie wykraczają poza kwestie procesowe i część z nich może być zaliczona do administracyjnego prawa materialnego albo stanowi wskazówki interpretacyjne dla wykładni tego prawa"18. Tym bardziej takich wypowiedzi o charakterze materialnoprawnym spodziewać się można w ustawach, których celem zasadniczym nie jest normowanie stosunków procesowoprawnych. Taką ustawą jest Pr.przeds. Z tych względów za celowe uznaje przyjęcie ${ }^{19}$ szerokiego rozumienia pojęcia zasad postępowania ${ }^{20}$, wychodząc poza wąskie odnoszenie tego pojęcia wyłącznie do zasad ujętych w normy, które wywołują skutek w sferze postępowania ${ }^{21}$.

W doktrynie prawa administracyjnego i postępowania administracyjnego wskazuje się na różne kategorie/typy zasad postępowania, koncentrując się na zasadach ogólnych k.p.a. ${ }^{22}$ Przy charakterystyce zasad postępowania unormowanych w Pr.przeds. z pewnością przydatne będzie wyróżnienie ${ }^{23}$ takich zasad, które w pierwszym rzędzie i w większym stopniu wpływają na przebieg postępowania (niejako „technicznych”, np. zasada załatwiania spraw bez zbędnej zwłoki) oraz takich, które nakładając obowiązki na organy - przyznają jednocześnie przedsiębiorcom szerokie uprawnienia procesowe (np. zasada pogłębiania zaufania do organów państwa, zasada udzielania przez organy informacji stronie/uczestnikom postępowania).

16 Tak też M. Zdyb, op. cit., s. 9.

17 Zob. B. Adamiak, op. cit., s. 13.

18 J. Zimmermann, op. cit., s. 171. Zob. tė̇ W. Piątek, Miejsce zasad ogólnych postepowania administracyjnego $w$ wyktadni przepisów prawa administracyjnego, w: J.P. Tarno, W. Piątek (red.), op. cit., s. 568-577.

19 Pojęcie zasad prawa jest wieloznaczne i wynika zawsze z jakiejś przyjętej konwencji. Zob. J. Zimmermann, op. cit., s. 162. Zob. też A. Wiktorowska, Teoretyczno-prawna koncepcja zasad ogólnych Kodeksu postęowania administracyjnego, „Studia Prawa Publicznego” 2013, nr 2, s. 13 - wskazana w przyp. 1 literatura.

${ }^{20}$ Tak też B. Popowska, Prawo działalności gospodarczej wobec wymogów dobrej administracji, w: J. Jagielski, D. Kijowski, M. Grzywacz (red.), Prawo administracyjne wobec współczesnych wyzwań. Ksiega jubileuszowa dedykowana Profesorowi Markowi Wierzbowskiemu, C.H. Beck, Warszawa 2018, s. 178-179.

21 B. Adamiak, op. cit., s. 13.

${ }^{22}$ Przyjmuję za B. Adamiak, że cechą charakterystyczną zasad ogólnych k.p.a. jest m.in. to, że znajdują one z reguły „współzastosowanie” z każdym przepisem Kodeksu, który w danym stadium postępowania jest stosowany i że nie wprowadzają one żadnych nowych, samoistnych instytucji, tj. że nie rozszerzają one katalogu instytucji postępowania administracyjnego. Zob. B. Adamiak, op. cit., s. 47.

${ }^{23}$ Zob. koncepcję systematyki zasad ogólnych kodeksu postępowania administracyjnego J. Zimmermann, op. cit., s. 171-172. 
Charakteryzując zasady unormowane w Pr.przeds. ${ }^{24}$, nie można pominąć wyodrębnianych w doktrynie zasad ogólnych postępowania, których treść wykracza poza postępowanie administracyjne i łączy się z niektórymi zasadami ogólnymi prawa administracyjnego, np. zasada praworządności i legalności (art. $6 \mathrm{i}$ art. 7 in principio k.p.a. ${ }^{25}$. Nawiąując do tej kategorii, należy podkreślić, że w Pr.przeds., z uwagi na jej podstawowy cel, którym jest wzmocnienie gwarancji wolności i praw przedsiębiorców, szczególne miejsce zajmują zasady określające podstawowe wartości w sferze stosunków gospodarczych, np. wolność działalności gospodarczej. Mimo rangi tych zasad i tej ich właściwości, że moga one wskazywać na sposoby dochodzenia do załatwienia konkretnej sprawy (rozstrzygnięcia) ${ }^{26}$, to z uwagi na ramy opracowania, nie będą one odrębnie omawiane.

\section{ZASADY POSTĘPOWANIA UNORMOWANE W ROZDZ. 1: PRZEPISY OGÓLNE}

Na wstępie należy stwierdzić, że projekt Pr.przeds. ${ }^{27}$ zawiera dość obszerne uzasadnienie, które omawia przedmiot regulacji nowej ustawy, z nawiązaniem do przepisów Konstytucji RP. Uzasadnienie projektu ustawy może stanowić pewną wskazówkę dla porządkowania jej przepisów ${ }^{28}$.

$\mathrm{W}$ uzasadnieniu projektu ustawy wskazuje się, że w jej rozdz. $1 \mathrm{w}$ art. 2 oraz art. 8-15 unormowane sa „podstawowe zasady wiążące samych przedsiębiorców oraz zasady wiążące organy władzy publicznej w ich relacjach z przedsiębiorcami”29. W tym opracowaniu rozważeniu podlega ta druga grupa zasad. Zostały one unormowane w następujących przepisach: 10, 11, 12, 14 i 15.

${ }^{24}$ Przyjęcie tego wzorca badań nie wyklucza charakteryzowania konkretnych zasad według innych kryteriów. Można zwłaszcza skorzystać z koncepcji wyróżniającej zasady podstawowe, które odzwierciedlają funkcje postępowania administracyjnego (zasada prawdy materialnej, zasada ochrony interesu indywidualnego i społecznego, zasada praworządności zasad przekonywania i zasada zaufania), oraz zasady im podporządkowane, które pełnią wobec zasad podstawowych funkcję instrumentalna, służą bowiem ich zabezpieczeniu i realizacji. Tak A. Wiktorowska, op. cit., s. 34.

${ }^{25}$ J. Zimmermann, op. cit., s. 171.

${ }^{26}$ Wnioski z rozważań dotyczących tej ostatnio wymienionej grupy zasad są bardzo ciekawe, pokazują wielopłaszczyznowość i skomplikowanie procesu stosowania prawa. Tak rozumiane zasady: zasady wolności działalności gospodarczej, zasada wspierania przez organy administracji państwowej rozwoju przedsiębiorczości, zasada działania organów na podstawie i w granicach prawa, z poszanowaniem uzasadnionych interesów przedsiębiorcy - były rozważane w świetle przepisów u.s.d.g., B. Popowska, Prawo działalności gospodarczej..., s. 179. Zob. także M. Strzelbicki, Zasada sprawiedliwości proceduralnej w procedurach publicznego prawa gospodarczego, w: B. Popowska (red.), Swoistość procedur publicznego prawa gospodarczego, Poznań 2013, s. 75.

${ }^{27}$ Uzasadnienie do projektu rządowego projekt ustawy - Prawo przedsiębiorców, druk sejmowy nr 2501 Sejmu VIII kadencji; zob. także stronę internetową Rządowego Centrum Legislacji: $<$ http://legislacja.rcl.gov.pl/>, (dalej jako: Projekt).

${ }^{28}$ Pamiętając, że dla organu orzekającego w sprawie wykładnia autentyczna, pochodząca od organu stanowiącego dane normy prawne, może mieć tylko znaczenie pomocnicze - L. Morawski, Wyktadnia w orzecznictwie sqdów. Komentarz, Toruń 2002, s. 42-43.

${ }^{29}$ Projekt, s. 24-25. 
Na podkreślenie zasługuje to, że większość tych zasad stanowi novum w regulacji prawa działalności gospodarczej (prawa przedsiębiorców). W tym zakresie można mówić o nowych zasadach procesowego publicznego prawa gospodarczego, i to niezależnie od faktu, że w wersji słownej treść niektórych z nich odpowiada treści zasad ogólnych k.p.a. Uwzględnić bowiem należy, że na treść normatywną poszczególnych zasad Pr.przeds. wpływ ma szereg jego przepisów, w tym określających zakres jego obowiązywania.

W powyższym rozumieniu nową instytucją prawa procesowego jest zasada zaufania do przedsiębiorcy (określana w uzasadnieniu Projektu jako zasada domniemania uczciwości przedsiębiorcy - art. 10 ust. 1$)^{30}$. Stanowi ona reakcję na często niezbyt przychylne przedsiębiorcom nastawienie organów władzy, wynikające z faktów naruszania przez przedsiębiorców prawa. Nakazuje ona organom władzy publicznej kierować się w swoich działaniach założeniem, że przedsiębiorca działał zgodnie z prawem, uczciwie oraz z poszanowaniem dobrych obyczajów. W sformułowaniu tej zasady zwraca uwagę jej szeroki zakres obowiązywania, który nie jest ograniczony do postępowań jurysdykcyjnych. Jest to zatem ogólna idea, która powinny kierować się organy w relacjach z przedsiębiorcami.

Uszczegółowieniem zasady zaufania do przedsiębiorcy jest, także nowa, zasada rozstrzygania wątpliwości faktycznych na korzyść przedsiębiorcy (art. 10 ust. 2). Zawiera ona jasne wytyczne dotyczące postępowania na etapie ustaleń faktycznych w sytuacjach, kiedy przedmiotem postępowania jest nałożenie na przedsiębiorcę obowiązku bądź ograniczenie lub odebranie uprawnienia. Ze wskazanych tu okoliczności wynika, że zasada ta ma obowiązywać w postępowaniach o charakterze jurysdykcyjnym. Nakaz rozstrzygania wątpliwości faktycznych na korzyść przedsiębiorcy powinien przeciwdziałać przedłużaniu czasu prowadzenia postępowania dowodowego, w sytuacji kiedy zajdą przesłanki do zastosowania wyżej wymienionej normy. Także i w tym aspekcie korzystnie wpływa na pozycję procesową przedsiębiorcy w postępowaniu.

Należy dodać, że zasada o tożsamym brzmieniu występuje w k.p.a. w rozdz. 4 o dowodach - art. 81a. Wprowadzona nowelą k.p.a. z 2017 zasada dotyczacca fazy postępowania dowodowego ma chronić stronę przed niekorzystnym rozstrzygnięciem w zakresie nałożenia obowiązku bądź ograniczenia lub odebrania uprawnienia ${ }^{31}$.

Nową jest, unormowana w art. 11, zasada rozstrzygania wątpliwości co do treści normy prawnej na korzyść przedsiębiorcy w sytuacjach, kiedy przedmiotem postępowania przed organem jest nałożenie na przedsiębiorcę obowiązku bądź ograniczenie lub odebranie uprawnienia ${ }^{32}$. Także i ta zasada odnosi się do postępowań jurysdykcyjnych. Podobnie jak w przypadku art. 10 ust. 2 Pr.przeds., konstrukcja tego przepisu pozwala uznać, że ideą zamieszczonej w nim normy

30 Zakres wyłączenia stosowania tego przepisu normuje art. 10 ust. 3.

31 B. Adamiak, op. cit., s. 460-461, o obiektywnej niemożności pełnego wyjaśnienia stanu faktycznego,

32 Zakres wyłączenia stosowania tego przepisu normuje art. 11 ust. 3. 
jest ochrona przedsiębiorcy przed negatywnymi konsekwencjami obiektywnej niemożności pełnego wyjaśnienia - tu: stanu prawnego.

Należy uwzględnić, że reguła ta, wywodzona dotychczas z konstytucyjnej zasady demokratycznego państwa prawa (art. 2), znalazła swój wyraz także w znowelizowanym w 2017 r. k.p.a. (art. 7a). W komentarzach do tego Kodeksu podkreśla się, że nawiązuje ona do wywodzonego z art. 7 k.p.a. domniemania załatwienia sprawy na korzyść strony. $\mathrm{W}$ istocie stanowi ona dyrektywę kierunkową wykładni przepisu materialnego prawa, który ma stanowić podstawę prawną rozstrzygnięcia sprawy ${ }^{33}$.

Kolejne zasady, po raz pierwszy wprowadzone do porządku publicznego prawa gospodarczego, nakazują prowadzenie przez organ postępowania w sposób budzący zaufanie przedsiębiorców do władzy publicznej, z uwzględnieniem zasad: proporcjonalności, bezstronności i równego traktowania (art. 12). Zasady tej samej treści znalazły miejsce wśród zasad ogólnych k.p.a., na mocy ostatniej nowelizacji - art. $8 \S 1$. Należy dodać, że wyrażone w obu źródłach prawa wytyczne dla organu sa zakorzenione w Konstytucji $\mathrm{RP}^{34}$. Warto zwrócić uwagę, że w komentarzu do k.p.a. wskazuje się na znaczenie zasad proporcjonalności, bezstronności i równego traktowania, zwłaszcza dla rozpoznania i rozstrzygnięcia sprawy indywidualnej na drodze decyzji ${ }^{35}$. Mając to spostrzeżenie na uwadze, wydaje się, że zakres obowiązywania (znaczenie) zasady unormowanej w art. 12 Pr.przeds. powinien wykraczać poza sprawy indywidualne, rozstrzygane $\mathrm{w}$ trybie postępowania administracyjnego. Jakie bowiem mogłoby być uzasadnienie nierespektowania tej zasady np. w postępowaniach o udzielenie pomocy publicznej?

Nową zasadą unormowaną w Prawie przedsiębiorców jest „zasada pewności działania organów”, określana też jako zasada pewności prawa - art. 14. $\mathrm{Na}$ jej znaczenie jako „fundamentu bezpieczeństwa prawnego” 36 wskazuje preambuła ustawy. Wprowadza ona dla organu zakaz odstępowania, bez uzasadnionej przyczyny, od utrwalonej praktyki rozstrzygania spraw w takim samym stanie faktycznym i prawnym. Zasada ta ma bezpośredni wpływ na treść rozstrzygnięcia ${ }^{37}$. W sformułowaniu tej reguły zwraca uwagę określenie sytuacji, w jakiej ma ona zastosowanie; chodzi o „rozstrzyganie spraw”, czyli - przyjmując rozumienie k.p.a. (art. $104 \S 2$ ), o postępowania wiążące się z wydawaniem decyzji - art. 104 k.p.a.). Wydaje się, że tylko takie rozumienie przypadków, w których zasada ta ma obowiązywać w sferze stosunków gospodarczych, jest możliwe. Trudno byłoby bowiem przekonywać do stosowania tej

${ }^{33}$ B. Adamiak, op. cit., s. 81-82. W doktrynie przepis ten został poddany krytyce, zob. W. Piątek, Kodeks postepowania administracyjnego $w$ świetle ustawy nowelizujacej z dnia 7 kwietnia 2017 r. - ogólna charakterystyka zmian, „Zeszyty Naukowe Sądownictwa Administracyjnego” 2017, z. 5, s. 23-24.

${ }^{34}$ Art. 31 ust. 3 - zasada proporcjonalności, art. 2 - zasada bezstronności wywodzona z zasady demokratycznego państwa prawa, art. 32 - zasada równości.

35 B. Adamiak, op. cit., s. 86.

36 Tak M. Zdyb, op. cit., s. 9.

37 Odrębną instytucją prawną unormowaną w Pr.przeds. jest „utrwalona praktyka interpretacyjna właściwego organu lub właściwej państwowej jednostki organizacyjnej” - art. 35 ust. 3 Pr.przeds.; jej omówienie przekracza ramy tego opracowania. 
zasady w innych postępowaniach, w których najczęściej jednym z kryteriów orzekania przez organ jest interes publiczny, a ta kategoria nie jest „wartością" stała, lecz zależy od okoliczności konkretnego przypadku ${ }^{38}$.

Nowela k.p.a. 2017 wprowadziła tożsamą treściowo zasadę, określana jako zasada jednolitości treści rozstrzygnięć dotyczących tożsamych przedmiotów spraw indywidualnych lub zasada uprawnionych oczekiwań w art. 8 $\S 2$. W doktrynie traktowana jest jako zasada realizacji zaufania do władzy publicznej ${ }^{39}$.

Realizacji zasady prowadzenia przez organ postępowania w sposób budzący zaufanie przedsiębiorców do władzy publicznej (art. 12 Pr.przeds.) służy nałożony na organ obowiązek udzielania przedsiębiorcy informacji o warunkach podejmowania, wykonywania i zakończenia działalności gospodarczej (art. 15) ${ }^{40}$. Ustawa doprecyzowuje, że obowiązek ten dotyczy informacji mieszczących się w zakresie właściwości organu, nie wyjaśnia jednak, o jakiego typu informacje chodzi; czy chodzi tylko o warunki/okoliczności faktyczne czy o warunki/ okoliczności prawne? Zapewne z dylematem tym będzie musiała zmierzyć się praktyka orzecznicza organów i orzecznictwo sądowoadministracyjne ${ }^{41}$.

$\mathrm{Z}$ pewnością warto, aby interpretując normę zawartą w art. 12 Pr.przeds., mieć na uwadze treść normatywna ,zasady informowania stron postępowania administracyjnego", wyrażonej w 9 k.p.a. Kodeks zasadę tę odnosi do postępowań administracyjnych, wskazując na dwa wymogi wiązane z udzielaniem informacji. Po pierwsze, organ ma obowiązek informować „należycie i wyczerpująco”, po drugie, informacja ma dotyczyć „okoliczności faktycznych i prawnych”. Nie wydaje się, aby w sferze podejmowania, wykonywania i zakończenia działalności gospodarczej takie standardy dobrej administracji, jak wskazane w art. 9 k.p.a., były niemożliwe do spełnienia. Nawiązuje do nich treść zasad unormowanych w rozdz. 3, zwłaszcza w art. 27.

Przed omówieniem zasad unormowanych w rozdz. 3 Pr.przeds. należy spróbować określić charakter (funkcję) zasad ujętych w rozdz. 1 Pr.przeds. Nawiązując do wyróżnionych w pkt 2 artykułu kategorii zasad postępowania, stwierdzić można, że w Przepisach ogólnych (w zakresie poddanym tu analizie)

${ }^{38}$ Zob. uwagi na temat postępowań, których podstawową funkcją nie jest kształtowanie pozycji prawnej przedsiębiorcy, a przesłanką wchodzenia w relacje zewnętrzne z przedsiębiorcami jest realizacja określonych celów (interesów) gospodarki, takich jak ochrona (przed tzw. wrogim przejęciem niektórych przedsiębiorców ze względu na znaczenie dla gospodarki, zachowanie integralności [ochrona] infrastruktury krytycznej, czy ochrona mienia państwowego) - B. Popowska, Nowe procedury..., s. 599-602.

39 Zob. B. Adamiak, op. cit., s. 87.

40 Można dodać, że również u.s.d.g. miała w spektrum swoich regulacji obowiąek organu udzielania informacji, których adresatami mieli być przedsiębiorcy - art. 8 ust. 2 i ust. 3. Jednakże regulacja ta miała inny zakres podmiotowo-przedmiotowy; kierowana do Polskiej Agencji Rozwoju Przedsiębiorczości dotyczyć miała warunków i form pomocy publicznej.

${ }^{41}$ Nie jest to jednak dylemat błahy w kontekście zasady unormowanej w art. 13 Pr.przeds., tj. zasady „ponoszenia przez funkcjonariuszy publicznych odpowiedzialności za naruszenie prawa spowodowane ich działaniem lub zaniechaniem. Por. szerokie ujęcie obowiązku informowania stron w postępowaniu administracyjnym, łącznie z czuwaniem, aby strony i inni uczestnicy postępowania nie ponieśli szkody z powodu nieznajomości prawa, i komentarz A. Borkowski, B. Adamiak, op. cit., s. 94-95. 
unormowane są zasady o różnym znaczeniu, zarówno takie, które nakładając obowiązki na organy - przyznają jednocześnie przedsiębiorcom uprawnienia procesowe (art. 10 ust. 1, art. 10 ust. 2), jak i takie, które w pierwszym rzędzie wpływają na przebieg postępowania (art. 15). Odrębnego potraktowania wymagaja zasady unormowane w art. 12 i art. 14, na ich procesowy wymiar nakładają się bowiem wartości o charakterze materialnoprawnym, nawiązujące wyraźnie do zasad konstytucyjnych, takich jak zasady: proporcjonalności, równego traktowania oraz zasada pewności prawa.

\section{ZASADY UNORMOWANE \\ W ROZDZ. 3: ZAŁATWIANIE SPRAW Z ZAKRESU DZIAŁALNOŚCI GOSPODARCZEJ}

Na wstępie stwierdzić należy, że przepisy rozdz. 3 Pr.przeds. nie „odwzorowują" (nie zawierają analogicznych) unormowań zawartych w rozdz. 7 k.p.a.: Załatwianie spraw ${ }^{42}$. Dotyczy to zarówno zakresu obowiązywania określonych w Pr.przeds. reguł, nie odnoszą się one bowiem głównie do „spraw administracyjnych $^{43}$ ani ich treści normatywnej ${ }^{44}$.

Ogólnie należy stwierdzić, że w rozdziale tym znajdują się przepisy o różnym charakterze pod względem stopnia ich ogólności i o różnej funkcji, w tym zasady stricte procesowe i zasady wykraczajace poza kwestie procesowe. Tylko niektórym z zasad unormowanych w Pr.przeds. można przypisać przymiot nowości, inne w istocie powtarzają treść reguł znanych u.s.d.g. bądź nawiązuja do instytucji wprowadzonych do porządku prawnego przez u.s.d.g.

Szczególne znaczenie w katalogu zasad unormowanych w rozdz. 3 Pr.przeds. maja: zasada szybkości postępowania - art. 27 oraz zasada współdziałania organów - art. 28. Są to nowe w porządku publicznego prawa gospodarczego zasady, których zakres obowiązywania nie ogranicza się do postępowań jurysdykcyjnych ${ }^{45}$.

Jeśli chodzi o „zasadę szybkości”, to art. 27 Pr.przeds., poza nakazem działania „szybko”, wskazuje też na „wnikliwość” działania organów i posługiwanie się przez nie „możliwie najprostszymi środkami prowadzącymi do załatwienia spraw”. Takie wytyczne dla organu, bez określenia terminów „załatwienia

${ }^{42}$ „Załatwienie sprawy” w rozumieniu art. 35 k.p.a. to wydanie decyzji albo załatwienie w innej formie określonej w Kodeksie.

${ }^{43}$ Obejmują one zatem także postępowania kontrolne oraz podatkowe; zob. uzasadnienie Projektu - s. 39 .

${ }^{44}$ Warto dodać, że żaden z artykułów opublikowanych w specjalnym dodatku do „Monitora Prawniczego" 2018, nr 13, nie odnosi się do całości regulacji rozdz. 3, w tym do art. 27 i art. 28, które wydają się kluczowe w tej grupie przepisów Pr.przeds.

${ }^{45}$ Art. 27 określa sposób działania organów „w sprawach związanych z wykonywaniem działalności gospodarczej”, do którego to zakresu należą także czynności kontrolne, art. 28 zaś nakazuje współdziałanie organów „w toku postępowania”, np. postępowania o wpis do Centralnej Ewidencji i Informacji o Działalności Gospodarczej (CEIDG). 
spraw” (jak w art. 35 § 3 i $§ 3 a$ k.p.a.), uwzględniają różnorodność i specyfikę działań administracji publicznej w sferze gospodarki.

Kontynuując w powyższym zakresie rozważania porównawcze z regulacją k.p.a., wyjaśnić należy, że przepis o niemal identycznej treści, jak art. 27 Pr.przeds., ujęty jest w art. 12 k.p.a., zamieszczonym w rozdz.: Zasady ogólne ${ }^{46}$. Znaczy to, że wyrażona w nim reguła („zasada szybkości i prostoty”), ze względu na jej doniosłość, uznana jest za zasadę ogólną postępowania administracyjnego ${ }^{47}$, a art. 35 i następne w rozdz. 7 k.p.a. określają instytucje (instrumenty), za pomoca których powinna być ona realizowana ${ }^{48}$. W Pr.przeds. dla „zasady szybkości” nie znalazło się miejsce w Przepisach ogólnych.

Tę samą konstatację można odnieść do zasady współdziałania organów, unormowanej w art. 28 Pr.przeds. W myśl tego przepisu: „W toku postępowania organy współdziałają ze sobą w zakresie niezbędnym do dokładnego wyjaśnienia stanu faktycznego i prawnego sprawy, mając na względzie interes społeczny i słuszny interes przedsiębiorców oraz sprawność postępowania, przy pomocy środków adekwatnych do charakteru, okoliczności i stopnia złożoności sprawy”. Należy zauważyć, że przepis ten nawiąuje do treści wyrażonych w tym samym rozdziale w art. 27 Pr.przeds. (przez nakaz działania sprawnego, za pomoca środków adekwatnych...), oraz do zasady bezstronności unormowanej w art. 12 Pr.przeds. (przez wymóg dążenia do dokładnego wyjaśnienia stanu faktycznego i prawnego sprawy).

Przede wszystkim jednak sformułowanie art. 28 Pr.przeds. każe porównać jego treść z treścią nowego art. 7b k.p.a., wprowadzonego nowelą z 2017. Poza uwzględnieniem, że k.p.a. normuje stosunki administracji z obywatelami, a Pr.przeds. - z przedsiębiorcami, zauważyć należy, że oba przepisy, tj. art. 28 Pr.przeds. i art. 7b k.p.a., zawierają tożsamą treść. Nie znaczy to jednak, że można im przypisać takie samo znaczenie i miejsce w katalogu zasad ujętych odpowiednio w k.p.a. i Pr.przeds. Rzecz w tym, że zamieszczony w rozdziale o zasadach ogólnych art. $7 \mathrm{~b}$ k.p.a. ${ }^{49}$ jest związany treściowo z art. 7 k.p.a., wyrażonej zaś w tym przepisie zasadzie prawdy obiektywnej k.p.a. nadał znaczenie uniwersalne. Tymczasem Pr.przeds. odnosi standardy procesowe realizacji prawdy obiektywnej do przypadków współdziałania organów. Takie zawężenie znaczenia tej zasady postępowania, która w ujęciu k.p.a. określana jest jako „naczelna”, wolałabym uznać za przeoczenie ustawodawcy niż za jego celowe działanie. Celowe i prawidłowe jest natomiast uwzględnienie w redakcji art. 28 Pr.przeds. faktu, że stroną postępowań prowadzonych przez organy

${ }^{46}$ Dodać należy, że treść aktualna tego przepisu pozostaje w istocie niezmieniona od początku obowiązywania k.p.a.

${ }_{47}$ Mimo że - co do istoty - jest dyrektywą prakseologiczna. Zob. M. Kotulska, Klasyfikacja zasad ogólnych postępowania, w: J.P. Tarno, W. Piątek (red.), op. cit., s. 415.

48 Zob. przyp. 24.

${ }^{49}$ Unormowana w tym przepisie z a sa da ws półd zi ała nia co do istoty jest dyrektywą prakseologiczną, której ze względu na jej doniosłość nadano znaczenie prawne, tak M. Kotulska, op. cit., s. 344 .

50 Zdaniem B. Adamiak na takie określenie zasada ta unormowana w Kodeksie zasługuje dlatego, że ma „[...] kapitalny wpływ na ukształtowanie całego postępowania [...]” - eadem, op. cit., s. 73 . 
administracji publicznej (nie musi przy tym chodzić ani o stronę w rozumieniu art. 28 k.p.a., ani o postępowanie jurysdykcyjne) jest przedsiębiorca.

Z tą ostatnią konstatacją wiąże się kwestia określenia standardów współdziałania w art. 28 Pr.przeds. Sa one tak unormowane jak w art. 7b k.p.a., z tą różnica, że Pr.przeds. nakazuje uwzględniać „interes społeczny” i „słuszny interes przedsiębiorcy” (a k.p.a.: „interes społeczny” i „słuszny interes obywatela"). Z racji ograniczonych ram opracowania należy przypomnieć, że w nauce prawa procesowego administracyjnego podkreśla się, że pojęcie „interesu społecznego" nie jest ustawowo zdefiniowane. To samo należy powiedzieć o „interesie przedsiębiorcy”. Z punktu widzenia teorii prawa oba pojęcia kwalifikowane sa jako klauzule generalne ${ }^{51}$. W konsekwencji należy przyjać, że ich treść zostanie zasadniczo ustalona dopiero w procesie stosowania prawa ${ }^{52}$.

Rozpoczynając rozważania w tym punkcie, podnoszono, że art. 27 i art. 28 Pr.przeds. znacznie różnią się od pozostałych przepisów zamieszczonych w rozdz. 3. W rozdziale tym ujęte są także zasady dotyczące czynności podejmowanych w postępowaniu, takich jak wyznaczanie przedsiębiorcy terminu na dokonanie określonej czynności (art. 30) oraz przyjmowanie pism i wniosków (art. 29 i art. 31-32) (53 $^{\text {. }}$

W kolejnych przepisach unormowano zasady dotyczące objaśnień prawnych (art. 33) oraz interpretacji indywidualnych (art. 34), które związane są z wykładnią przepisów prawnych z zakresu działalności gospodarczej, z tym że interpretacje indywidualne dotyczyć mogą wyłącznie przepisów z zakresu danin publicznych lub składek na ubezpieczenia społeczne lub zdrowotne. Z pewnością nie jest to rozdział o spójnej konstrukcji i treści podporządkowanej tytułowi rozdziału.

\section{PODSUMOWANIE}

Na podkreślenie zasługuje fakt, że Prawo przedsiębiorców normuje w znacznie szerszym zakresie, aniżeli czyniły to poprzednie ustawy, ogólne zasady postępowania w zakresie działalności gospodarczej. Można wręcz mówić o nowym charakterze (modelu) ustawy normujacej podejmowanie i wykonywanie działalności gospodarczej, która obok przepisów prawa materialnego

51 Eadem, op. cit., s. 71. Ta sama konstatacja dotyczy interesu obywatela.

52 Zob. m.in. E. Łętowska, Interpretacje a subsumpcja zwrotów niedookreślonych i nieostrych, „Państwo i Prawo” 2011, z. 7-8, s. 17. Jeśli chodzi o interes przedsiębiorcy, to na uwagę zasługuje zwłaszcza teza wyrażona w uchwale SN z 23 lutego 1995 r.: „Interes przedsiębiorcy należy rozumieć jako sytuację korzystnie dla przedsiębiorcy ukształtowaną lub mogącą w przyszłości stanowić dla niego źródło korzyści rzeczywistych lub tylko oczekiwanych” (III CZP 12/95, OSNC 1995, nr 5, poz. 80).

${ }^{53}$ Zasady unormowane w wymienionych przepisach pełnią funkcję instrumentalną wobec zasad wskazanych wyżej, służąc zabezpieczeniu ich realizacji. 
zawiera liczne przepisy proceduralne, w tym zwłaszcza określające zasady ogólne postępowania.

Ich ujęcie redakcyjne wskazuje, że nie odnoszą się one wyłącznie do postępowań o charakterze jurysdykcyjnym. Niektóre z zasad powinny znajdować zastosowanie także w takich postępowaniach, jak kontrola działalności gospodarczej czy postępowanie o wpis do CEIDG, a nawet w takich, których przedmiotu Pr.przeds. w ogóle nie reguluje, jak postępowania w sprawie pomocy publicznej (art. 12). Ten wniosek wiąże się z rangą ustawy i uniwersalnym charakterem zasad ${ }^{54}$.

Powyższą uwagę należy uzupełnić o stwierdzenie, że niektóre spośród unormowanych w Pr.przeds. reguł postępowania w relacjach administracja publiczna - przedsiębiorca powtarzaja zasady unormowane w k.p.a. (por. art. 28 Pr.przeds. i art. 7b k.p.a.). W uzasadnieniu Projektu wyjaśnia się, że celem takiej „wyraźnej rekapitulacji” zasad w Pr.przeds. jest dostarczenie informacji przedsiębiorcom i zwiększenie ich świadomości prawnej (s. 25). W związku z tym, że Prawo przedsiębiorców jest ustawą podstawowa, takie powtórzenia treści przepisów zawartych w innych źródłach prawa mieszczą się w granicach reguł prawidłowej legislacji. Ważne przy tym jest, że normując zasady treściowo tożsame z tymi unormowanymi w k.p.a., Pr.przeds. tym samym przenosi na płaszczyznę publicznego prawa gospodarczego podstawowe zasady (wartości, idee) Konstytucji RP (np. art. 12) .

Na podkreślenie zasługuje też fakt, że obok przepisów, które normują tożsame co do treści zasady postępowania, jak w k.p.a., Pr.przeds. normuje szereg nowych zasad, nieznanych poprzednim ustawom dotyczącym działalności gospodarczej, w tym takie, które wyrażają idee ujęte po raz pierwszy w formę obowiązujących norm prawnych. Szczególnym przykładem jest zasada zaufania do przedsiębiorcy (art. 10 ust. 1). Nie było takiej zasady w dotychczasowym porządku prawnym, zatem wyraża ona nowy standard w relacjach administracja publiczna - przedsiębiorca. Unormowanie tej zasady wzmacnia gwarancje procesowe dla przedsiębiorców.

Słabościa Pr.przeds. jest to, że omawiane tu zasady zamieszczone sa w dwóch rozdziałach, przy czym niejasne są tego kryteria. Można zaakceptować tradycyjne już umiejscowienie „zasad podstawowych” (na taki zamysł ustawodawcy wskazuje uzasadnienie Projektu) w rozdz. 1: Przepisy ogólne. Jednakże treść rozdz. 3: Załatwianie spraw z zakresu działalności gospodarczej nastręcza sporo wątpliwości. Wydaje się, że również w tym rozdziale znajdują się zasady ogólne, odzwierciedlające funkcje postępowania, takie jak zasada prawdy obiektywnej, ochrony interesu społecznego i słusznego interesu przedsiębiorców (art. 28). Z pewnością swoim charakterem różnią się one od zasad o charakterze instrumentalnym, które dotyczą poszczególnych czynności postępowania (art. 28-31), nie mówiąc o regulacji zagadnień zwią-

54 Pogląd, że zasady unormowane w Pr.przeds. dotyczą całego systemu prawa gospodarczego, wyraża też M. Zdyb, op. cit., s. 9 i 12.

${ }_{55} \mathrm{~W}$ tym miejscu nie mogę zgodzić się ze stanowiskiem autora uzasadnienia Projektu (tak można zrozumieć wyrażoną myśl na s. 25), jakoby zasady konstytucyjne były „normami programowymi”. 
zanych z wykładnią przepisów prawa („objaśnienia prawne” i „interpretacje indywidualne”).

Uwzględniając powyższy wniosek oraz wcześniejszej uwagi, jestem zdania, że mimo iż zasady postępowania unormowane w Prawie przedsiębiorców nie stanowią spójnego zbioru, to z uwagi na ich uniwersalny charakter oraz rangę i miejsce tej ustawy w obszarze publicznego prawa gospodarczego, moga służyć za bazę normatywną proceduralnego publicznego prawa gospodarczego.

prof. dr hab. Bożena Popowska

Uniwersytet im. Adama Mickiewicza w Poznaniu

prawogos@amu.edu.pl

https://orcid.org/0000-0002-7453-6129

\section{RULES OF PROCEDURE IN MATTERS RELATED TO BUSINESS ACTIVITY REGULATED BY THE LAW ON ENTREPRENEURS}

Sum mary

The Act of 6 March 2018: Law on Entrepreneurs regulates the rules connected with undertaking and performing economic activity in a very different way than the previously binding Act of 2 July 2004 on Freedom of Economic Activity. The provisions on the procedure concerning the relations between public administration and entrepreneurs are to a large extent a new matter of public economic law. The procedural rules are included in Chapter I: General provisions and Chapter III: Settlement of matters related to economic activity. Some of the rules repeat the general principles of administrative proceedings regulated in the Code of Administrative Procedure (Article 28 of the Act and Article $7 \mathrm{~b}$ of the Code of Administrative Procedure). In this way Law on Entrepreneurs transfers the basic principles (values, ideas) of the Constitution of the Republic of Poland (Article 12) to the area of public economic law. The Act also regulates a number of new rules, including those that express ideas which are included for the first time in the form of binding legal norms. A specific example is the principle of trust in the entrepreneur (Article $10[1])$, which articulates a new standard in relations between public administration and the entrepreneur. The regulation of this principle strengthens procedural guarantees for entrepreneurs. Despite the fact that the rules of conduct regulated in the Law on Entrepreneurs do not constitute a coherent set, due to their universal character and the rank and place of this Act in the area of public commercial law, they may serve as a normative basis for procedural public commercial law. 